Review

\title{
Amino Acid Profiles in Term and Preterm Human Milk through Lactation: A Systematic Review
}

\author{
Zhiying Zhang ${ }^{1}$, Alicia S. Adelman ${ }^{2}$, Deshanie Rai ${ }^{2, \dagger}$, Julia Boettcher ${ }^{2, *}$ and Bo Lőnnerdal ${ }^{3}$ \\ 1 Department of Kinesiology and Community Health, University of Illinois at Urbana-Champaign, \\ Urbana, IL 61801, USA; E-Mail: zzhang26@illinois.edu \\ 2 Mead Johnson Pediatric Nutrition Institute, Evansville, IN 47721, USA; \\ E-Mails: adelman.alicia@gmail.com (A.S.A.); deshanierai@gmail.com (D.R.) \\ 3 Department of Nutrition, University of California, Davis, CA 95616, USA; \\ E-Mail: bllonnerdal@ucdavis.edu \\ $\dagger$ Current Address: DSM Nutritional Products, Inc., Parsippany, NJ 07054, USA. \\ * Author to whom correspondence should be addressed; E-Mail: julia.boettcher@mjn.com; \\ Tel.: +1-812-429-5113.
}

Received: 15 June 2013; in revised form: 28 October 2013 / Accepted: 31 October 2013 /

Published: 26 November 2013

\begin{abstract}
Amino acid profile is a key aspect of human milk (HM) protein quality. We report a systematic review of total amino acid (TAA) and free amino acid (FAA) profiles, in term and preterm HM derived from 13 and 19 countries, respectively. Of the 83 studies that were critically reviewed, 26 studies with 3774 subjects were summarized for TAA profiles, while 22 studies with 4747 subjects were reviewed for FAA. Effects of gestational age, lactation stage, and geographical region were analyzed by Analysis of Variance. Data on total nitrogen (TN) and TAA composition revealed general inter-study consistency, whereas FAA concentrations varied among studies. TN and all TAA declined in the first two months of lactation and then remained relatively unchanged. In contrast, the FAA glutamic acid and glutamine increased, peaked around three to six months, and then declined. Some significant differences were observed for TAA and FAA, based on gestational age and region. Most regional TAA and FAA data were derived from Asia and Europe, while information from Africa was scant. This systematic review represents a useful evaluation of the amino acid composition of human milk, which is valuable for the assessment of protein quality of breast milk substitutes.
\end{abstract}


Keywords: protein; non-protein nitrogen; breast milk; infant nutrition

\begin{abstract}
Abbreviations
HM, human milk; TN, total nitrogen; TAA, total amino acids; FAA, free amino acids; IEG, International Expert Group; NPN, Non-protein nitrogen; AP, Asia; EU, Europe; NA, North America; AF, Africa; ANOVA, Analysis of Variance; IAA, Indispensable amino acids; DAA, Dispensable amino acids; NS, Not-specified; PC, Principal component; Mo, month; Wk, week; Yr, year; H, hour; d, day; g, gram; LS, least-squares; Leu, Leucine; Lys, Lysine; Phe, Phenylalanine; Val, Valine; Trp, Tryptophan; Thr, Threonine; Met, Methionine; Ile, Isoleucine; Tau, Taurine; Arg, Arginine; Ala, Alanine, Asp, Aspartate; His, Histidine; Tyr, Tyrosine; Pro, Proline; Gly, Glycine; Ser, Serine; Glu, Glutamate; Gln, Glutamine; Cys, Cysteine; Colo, Colostrum; Trans, Transitional; MT, Mature; LacStage, Lactation Stage
\end{abstract}

\title{
1. Introduction
}

Protein quality and quantity are key aspects of the nutritional value of infant feedings. Although several factors influence protein quality, the amino acid profile of the feeding is well recognized and documented as a contributor to overall protein quality. The protein composition of infant feedings may be evaluated with an amino acid score that is based on human milk amino acid composition [1].

Many of the available references on the amino acid composition of human milk provide values in quantities of total protein or total nitrogen without considering the differences between crude protein derived from total nitrogen and true protein from protein nitrogen. Total amino acids (TAA) are comprised of amino acids contributing to both protein nitrogen (protein-bound amino acids) and non-protein nitrogen (NPN) [2]. A large proportion (around 20\%-25\%) of total nitrogen in human milk is non-protein nitrogen; free amino acids (FAA) account for $8 \%-22 \%$ of NPN and $5 \%-10 \%$ of TAA [3-6]. Taurine, glutamic acid, and glutamine are the most abundant free amino acids in human milk, with glutamic acid and glutamine comprising nearly 50\% of total free amino acids [7-10]. Free amino acids contribute to the body's utilizable nitrogen, are credited for the initial change in plasma free amino acids following a feed, and are more readily absorbed than protein-derived amino acids [5,11]. Increasing evidence suggests that free amino acids may play an important role in early postnatal development, yet their full biological significance has not been fully defined $[5,12]$.

Advances in infant nutrition composition and functionality often begin with a more thorough understanding of human milk. We know of no single comprehensive systematic review of human milk amino acid profiles available in peer-reviewed literature that can serve as a reference for amino acid composition of preterm and term infant feedings. Although preterm human milk is not considered nutritionally adequate to support the intrauterine growth and development of preterm infants [13], human milk offers several physiological and psychological benefits, and experts recommend fortified human milk for preterm infants [14]. Therefore, an understanding of preterm human milk composition is an important step in providing optimal nutrition to this vulnerable population. 
This systematic review considered both total and free amino acid profiles in term and preterm breast milk, from mothers living in various geographic locations, from all available literature worldwide. Our goal was to report human milk amino acid concentration from women around the world and throughout the course of lactation, to determine the effects of gestational age, geography, and stage of lactation on the concentration of total and free amino acids.

\section{Experimental Section}

\subsection{Data Origin}

A search of the literature using PubMed, Scopus, EMBASE, Google Scholar, and ProQuest Dissertations \& Theses (PQDT) was performed with the keywords "breast milk" or "human milk" and "amino acid". The most recent search was conducted in February 2010. We also reviewed reference lists to identify any articles not found using online methods. Some reports were translated into English as needed. All data were obtained from original reports.

Data pertaining to the amino acid composition in human milk were categorized by gestational age, stage of lactation, and country. A summary was prepared using the means reported in the literature. The countries were grouped into the wide geographical regions of Asia/Pacific (AP), Europe (EU), North America (NA), and Africa (AF). If gestational age was not specified (i.e., preterm or term), the article was included and categorized as not-specified (NS). Stages of lactation were categorized as colostrum ( $0-5$ days), transitional (6-20 days), and mature ( $\geq 21$ days).

As there were a large number of mature milk studies, mature milk was further classified into subgroups based on the lactation day. Many studies provided the lactation ranges of pooled milk samples rather than a specific day; these studies were grouped based on their average lactation day. Compared to TAA, fewer studies were found on the FAA profile of mature human milk. Therefore, three subgroups of mature milk (MT) were identified for TAA studies, whereas only two subgroups were named for FAA. Subgroup labels indicate the last lactation day included in that subgroup: MT2mo (21-58 days), MT4mo (59-135 days), and MT18mo (136-540 days) for TAA and MT2mo (21-60 days) and MT $>2$ mo ( $\geq 61$ days) for FAA.

\subsection{Inclusion Criteria}

To be included in this review, the following criteria had to be met. For term human milk, data had to be from studies of "normal" or "healthy" mothers who delivered healthy term infants. Additionally, these mothers had to be consuming free-living diets; data from mothers consuming special diets were excluded. For preterm human milk, data had to be from studies of "normal" or "healthy" mothers who delivered an appropriate for gestational age preterm infant. Due to the paucity of available data on preterm infants, no study was excluded based on infant health or the lack of information thereof. Sufficient information on milk sampling, including stage of lactation, units used to express amino acid concentration, and geographic location also had to be stated. Data from only one mother, means derived from a collection of studies, broad stage of lactation (i.e., mean of all or most stages of lactation), or duplicated representations of data, were excluded. Milk could be obtained with mechanical, electrical, and hand pumps or by manual expression; samples were transported and stored 
in either liquid or freeze-dried form; defatted or whole milk was used for hydrolysis. Other variables such as age, ethnicity, body weight, socioeconomic status, and season were not considered. Milk samples were from complete $24 \mathrm{~h}$ collections, or at least the entire amount of milk from one or both breasts at a feeding, or pooled or banked milk. Studies that used ion exchange chromatography analytical method or specifically indicating using an automatic amino acid analyzer to quantify the amino acids (preceded by hydrolysis for TAA) were included. Studies were excluded if the amino acid contents were determined by microbiological methods. Methods for detection of methionine, cysteine, and tryptophan were evaluated to ensure consistency.

\subsection{Data Analysis and Standard Unit Conversion}

The mean amino acid concentrations in human milk were calculated by averaging the mean values for each included publication. In most studies, total amino acid concentrations were reported in quantities per $100 \mathrm{~mL}$ of milk. Free amino acids were usually reported as $\mu \mathrm{mol} / \mathrm{L}$ of milk. For data expressed in units per $100 \mathrm{~g}$, the volume-weight correction was ignored. To provide a comparison to the published recommendations, total amino acid concentrations were converted to concentrations per $g$ of total nitrogen while also considering the differences between true and crude protein. The conversion factor of 6.25 was used when applicable. In one study [15], the total nitrogen content was not reported. However, true protein content was detected by the Lowry method [16]. The calculation of total nitrogen was rendered possible by the evidence that only about $80 \%$ of the nitrogen in mature human milk is protein nitrogen [17].

Most reports gave means, standard deviations, number of subjects, and number of pooled samples. When "number of subjects" alone was given or values were given for individuals, one breast milk sample was assumed for each subject. For this reason, data were treated as independent in the statistical analysis.

Analysis of Variance (ANOVA) was used to compare the effect of gestational age, lactation stage, and region on TAA and FAA of HM using the SAS $^{\circledR}$ software (version 9.1; SAS Institute, Cary, NC, USA).

\section{Results}

\subsection{The Dataset}

The human milk composition literature reviewed is listed in Tables $1-3$. We reviewed 83 articles from 18 countries with publication dates ranging from 1941 to 2009 that provided total and/or free amino acid content in human milk for one or more lactation stages in term and/or preterm milk. Based on the inclusion criteria, twenty-six articles providing 79 mean values from 3774 subjects for TAA (Table 1), and 22 studies providing 65 mean values from 4747 subjects for FAA (Table 2) were included in this analysis. Table 3 lists those studies that were excluded from this review. The number of studies was globally unbalanced through all lactation stages and regions. For instance, there were more data from Asia, while there was a paucity of data from Africa. Data on total nitrogen and total amino acid composition of human milk revealed general inter-study consistency, whereas marked variability was seen in the values of the free amino acids between studies. 
Table 1. Included studies on total amino acid profiles of human milk.

\begin{tabular}{lccc}
\hline \multicolumn{1}{c}{ Reference } & Region & Country & Term \\
\hline Atkinson 1980 [18] & NA & Canada & Preterm and Term \\
Bellomonte 1990 [19] & EU & Italy & Not Specified \\
Britton 1986 [15] & NA & USA & Preterm and Term \\
Chavalittamrong 1981 [20] & AP & Thailand & Not Specified \\
Cheung, Pratt, and Fowler 1953 [21] & NA & Puerto Rico & Not Specified \\
Darling 1997 and 1999 [22,23] & NA & Canada & Preterm \\
Darragh 1998 [24] & AP & New Zealand & Term \\
Davis 1994 [25] & NA & USA & Not Specified \\
Donovan 1989 [26] & NA & USA & Term \\
Feng 2009 [27] & EU, NA, SA & 9 Countries & Not Specified \\
Hanning 1992 [28] & NA & Canada & Term \\
Harzer 1985 [29] & EU & Germany & Term \\
Janas 1986 [30] & NA & USA & Term \\
Janas 1987 [31] & NA & USA & Term \\
Lauber 1979 [32] & AF & Ivory Coast & Not Specified \\
London Department of Health [33] & EU & England & Term \\
Lönnerdal 1976 [34] & EU & Sweden & Not Specified \\
Lönnerdal 1985 [35] & EU & Sweden & Not Specified \\
Sarwar 1996 [36] & NA & Canada & Preterm and Term \\
Shaikhiev 1978 [37] & AP & Russia & Not Specified \\
Svanberg 1977 [6] & AF & Ethiopia and Sweden & Not Specified \\
Villapando 1998 [38] & NA & USA and Mexico & Term \\
Wu 2000 [39] & AP & Taiwan & Term \\
Yamawaki 2005 [40] & AP & Japan & Term \\
Yonekubo 1989 [41] & AP & Japan & Not Specified \\
Zhao 1989 [42] & AP & China & Term \\
\hline
\end{tabular}

Table 2. Included studies on free amino acid profiles of human milk.

\begin{tabular}{lccc}
\hline \multicolumn{1}{c}{ Reference } & Region & Country & Term \\
\hline Agostoni 2000 [3] & EU & Italy & Term \\
Agostoni 2000 [7] & EU & Italy & Term \\
Armstrong 1963 [43] & NA & USA & Not Specified \\
Atkinson 1980 [18,44] & NA & Canada & Preterm and Term \\
Carratù 2003 [5] & EU & Italy & Term \\
Chuang 2005 [8] & AP & Taiwan & Preterm and Term \\
Darling 1997 and 1999 [22,23] & NA & Canada & Preterm \\
DeSantiago 1998 [45] & NA & Mexico & Not Specified \\
Donovan 1989 [26] & NA & USA & Not Specified \\
Elmastas 2008 [9] & AP & Turkey & Term \\
Gutikova 2001 [46] & AP & Russia & Not Specified \\
Harzer 1984 [47] & EU & Germany & Term \\
Lemons 1983 [2] & NA & USA & Preterm and Term \\
López-Sánchez Solís 1988 [48] & EU & Spain & Not Specified \\
\hline
\end{tabular}


Table 2. Cont.

\begin{tabular}{lccc}
\hline Motil 1995 [49] & NA & USA & Term \\
Pamblanco 1989 [11] & EU & Spain & Preterm and Term \\
Rassin 1977 [50] & EU and NA & Finland and USA & Not Specified \\
Singh 2004 [51] & AP & India & Term \\
Viña 1987 [52] & EU & Spain & Not Specified \\
Wu 2000 [39] & AP & Taiwan & Term \\
Wurtman 1979 [53] & NA & USA and Guatemala & Not Specified \\
Yonekubo 1989 [41] & AP & Japan & Not Specified \\
\hline
\end{tabular}

Table 3. Excluded studies on total and free amino acid profiles of human milk.

\begin{tabular}{|c|c|}
\hline Study & Reason for Exclusion \\
\hline \multicolumn{2}{|l|}{ Total Amino Acids } \\
\hline Beach $1941[54]$ & Microbiological determination \\
\hline Block $1946[55]$ & Microbiological determination \\
\hline Davis 1993 [56] & Mean from many studies; Duplicate representation \\
\hline Davis 1994 [57] & No total nitrogen or total protein reported \\
\hline DeSantiago 1999 [58] & Marginally nourished lactating women \\
\hline Flippova 1974 [59] & No method for amino acid quantification \\
\hline Guo 2007 [60] & Single milk donor \\
\hline Heine 1991 [61] & Same data as Renner 1983 \\
\hline Järvenpää 1982 [62] & Same data as Rassin 1976 \\
\hline Lemons 1983 [2] & Only protein-bound amino acid profiles excluded \\
\hline Macy 1949 [63] & Microbiological determination \\
\hline Macy $1961[64]$ & Microbiological determination \\
\hline Miller 1950 [65] & Microbiological determination \\
\hline Mitton 1992 [66] & Source of amino acid values not given \\
\hline Motil 1995 [49] & Only protein-bound amino acid profiles excluded \\
\hline Nagasawa 1970 [67] & Casein amino acid profile \\
\hline Nayman 1979 [68] & Mean from many studies; duplicate representation; microbiological determination \\
\hline Picone 1989 [69] & $\begin{array}{l}\text { No information given on milk sampling, number of samples, or method of amino } \\
\text { acid quantification }\end{array}$ \\
\hline Räihä 2002 [70] & Same data as Nayman 1979 \\
\hline Rassin 1977 [50] & Lactation stage unclear \\
\hline Renner 1983 [71] & Duplicate representation \\
\hline Rigo 1994 [72] & Same data as Harzer 1985 \\
\hline Saito 1975 [73] & Microbiological determination; lactation stage unclear \\
\hline Scott $1990[74]$ & No information given on milk sampling or method of amino acid quantification \\
\hline Soupart 1954 [75] & Lactation stage unclear \\
\hline Tikanoja 1982 [76] & Lactation stage unclear \\
\hline Volz 1983 [77] & Same as Agricultural Handbook 1976 \\
\hline Williamson 1944 [78] & Lactation stage unclear \\
\hline Woodward 1976 [79] & Casein amino acid profile \\
\hline
\end{tabular}


Table 3. Cont.

\begin{tabular}{ll}
\hline Free Amino Acids & \\
\hline Farriauz 1971 [80] & Single milk donor \\
Faus 1984 [81] & Data presented only in chart form \\
Ghadimi 1963 [82] & Values unconvertible \\
Nayman 1979 [68] & References by microbiological determination, duplicated representation \\
Pajarón 1992 [83] & Values represent mean of all stages of lactation \\
Periago 1994 [84] & Values represent mean of all stages of lactation \\
\hline
\end{tabular}

\subsection{Effect of Lactation Stage}

The distribution of total and free amino acid concentrations by least-squares means (LS means) according to lactation stage is shown in Tables 4 and 5, respectively. Total nitrogen and each of the 18 individual total amino acids in human milk sharply declined in the first two months of lactation followed by a considerably slower rate of decrease (Table 4). While concentrations of most individual free amino acids steadily decreased with the progression of lactation, glutamate and glutamine steadily increased after three weeks of lactation, and yielded the greatest level in late mature milk (Table 5). The most abundant was glutamate, with a concentration around 20 times higher than that of other free amino acids, ranging from 960.1 to $1529.0 \mu \mathrm{mol} / \mathrm{L}$ (Table 5). Taurine was also abundant, with an average of $287.1 \mu \mathrm{mol} / \mathrm{L}$ by 2 mo of lactation.

\subsection{Geographical Distribution}

A comparison of the TAA and FAA values among the different geographical continents (Africa, Asia, Europe, and North America) is illustrated in Figures 1 and 2. In regards to TAA, tyrosine appeared to be significantly greater in milk derived from African mothers versus the other regions. On the other hand, levels of proline, histidine, methionine, and tryptophan were lowest in milk derived from North American mothers (Figure 1).

For FAA, there were no data from Africa. Overall, alanine, phenylalanine, methionine, and isoleucine were significantly higher in milk from Asian mothers. Interestingly, glutamate levels were greatest in milk from North America (Figure 2).

\subsection{Effect of Gestational Age}

Only six references were available on preterm total amino acids. These milk samples were collected from 5 to 25 days after birth with an average of 12.5 days postpartum, all from North America. The effect of gestational age was examined by comparing the concentrations of total amino acids and total nitrogen from these six references to that of term transitional milk (Table 6). Results showed that TAA and TN levels were generally higher in preterm human milk than term milk. The concentrations of valine, threonine, and arginine were significantly greater in preterm than term transitional milk. Although preterm milk had higher total nitrogen content than term milk, the difference was not statistically significant. 
Table 4. Least-square means of human milk total amino acid (TAA) and total nitrogen (TN) content according to lactation stage (Amino acid values in $\mathrm{mg} / 100 \mathrm{~mL}$; $\mathrm{TN}$ values in $\mathrm{g} / \mathrm{L})^{\S, *, \dagger}$.

\begin{tabular}{cccccc}
\hline & \multicolumn{5}{c}{ Lactation Stage } \\
\cline { 2 - 6 } AA & Colo & Trans & MT 2 mo & MT4mo & MT18mo \\
\hline AAA & \multicolumn{5}{c}{} \\
\hline His & $57.0^{\mathrm{a}}$ & $38.7^{\mathrm{b}}$ & $29.1^{\mathrm{c}}$ & $26.5^{\mathrm{c}}$ & $24.6^{\mathrm{c}}$ \\
Leu & $206.2^{\mathrm{a}}$ & $147.2^{\mathrm{b}}$ & $118.8^{\mathrm{c}}$ & $104.6^{\mathrm{d}}$ & $94.5^{\mathrm{d}}$ \\
Lys & $141.8^{\mathrm{a}}$ & $99.6^{\mathrm{b}}$ & $82.2^{\mathrm{c}}$ & $68.9^{\mathrm{d}}$ & $66.8^{\mathrm{d}}$ \\
Phe & $95.3^{\mathrm{a}}$ & $59.2^{\mathrm{b}}$ & $46.0^{\mathrm{c}}$ & $39.0^{\mathrm{d}}$ & $43.9^{\mathrm{cd}}$ \\
Val & $125.3^{\mathrm{a}}$ & $79.1^{\mathrm{b}}$ & $67.0^{\mathrm{c}}$ & $58.0^{\mathrm{d}}$ & $54.8^{\mathrm{d}}$ \\
Trp & $43.3^{\mathrm{a}}$ & $30.7^{\mathrm{b}}$ & $24.3^{\mathrm{c}}$ & $20.1^{\mathrm{d}}$ & $21.4^{\mathrm{cd}}$ \\
Thr & $119.3^{\mathrm{a}}$ & $72.3^{\mathrm{b}}$ & $54.9^{\mathrm{c}}$ & $47.2^{\mathrm{d}}$ & $45.6^{\mathrm{d}}$ \\
Met & $28.7^{\mathrm{a}}$ & $21.3^{\mathrm{b}}$ & $17.8^{\mathrm{c}}$ & $16.6^{\mathrm{cd}}$ & $14.3^{\mathrm{d}}$ \\
Ile & $93.5^{\mathrm{a}}$ & $79.5^{\mathrm{b}}$ & $64.7^{\mathrm{c}}$ & $54.8^{\mathrm{d}}$ & $51.6^{\mathrm{d}}$ \\
\hline $\boldsymbol{D A A}$ & & & & & \\
\hline Arg & $102.9^{\mathrm{a}}$ & $62.0^{\mathrm{b}}$ & $44.5^{\mathrm{c}}$ & $37.4^{\mathrm{d}}$ & $35.0^{\mathrm{d}}$ \\
Ala & $110.7^{\mathrm{a}}$ & $59.3^{\mathrm{b}}$ & $48.1^{\mathrm{c}}$ & $39.2^{\mathrm{c}}$ & $39.5^{\mathrm{d}}$ \\
Asp & $207.3^{\mathrm{a}}$ & $138.6^{\mathrm{b}}$ & $107.2^{\mathrm{c}}$ & $90.9^{\mathrm{d}}$ & $85.3^{\mathrm{e}}$ \\
Tyr & $100.3^{\mathrm{a}}$ & $69.5^{\mathrm{b}}$ & $52.8^{\mathrm{c}}$ & $50.2^{\mathrm{c}}$ & $49.3^{\mathrm{c}}$ \\
Pro & $165.3^{\mathrm{a}}$ & $125^{\mathrm{b}}$ & $100.3^{\mathrm{c}}$ & $94.9^{\mathrm{c}}$ & $88.3^{\mathrm{c}}$ \\
Gly & $66.2^{\mathrm{a}}$ & $38.1^{\mathrm{b}}$ & $28.9^{\mathrm{c}}$ & $24.3^{\mathrm{d}}$ & $23.5^{\mathrm{d}}$ \\
Ser & $119^{\mathrm{a}}$ & $74.1^{\mathrm{b}}$ & $52.7^{\mathrm{c}}$ & $47.2^{\mathrm{cd}}$ & $44.1^{\mathrm{d}}$ \\
Glu & $332.7^{\mathrm{a}}$ & $241.9^{\mathrm{b}}$ & $201.3^{\mathrm{c}}$ & $189.2^{\mathrm{cd}}$ & $174.4^{\mathrm{d}}$ \\
Cys & $50.2^{\mathrm{a}}$ & $31.0^{\mathrm{b}}$ & $23.5^{\mathrm{c}}$ & $23.9^{\mathrm{c}}$ & $21.2^{\mathrm{c}}$ \\
TN & $\mathbf{3 . 5 ^ { \mathrm { a } }}$ & $\mathbf{2 . 6} \mathbf{6}^{\mathrm{b}}$ & $\mathbf{2 . 1}^{\mathrm{c}}$ & $\mathbf{1 . 9}^{\mathrm{d}}$ & $\mathbf{1 . 7}^{\mathrm{d}}$ \\
\hline
\end{tabular}

IAA: Indispensable amino acids are those that are essential to the infant [85]. DAA: Dispensable amino acids are those amino acids that are non-essential [85]. ${ }^{\S}$ Colo (0-5 days), Trans (6-20 days), MT2mo (21-58 days), MT4mo (59-135 days), MT18mo (136-540 days). * Means that do not share a common superscript letter are significantly different $(p<0.05) .{ }^{\dagger}$ Includes milk from term and not-specified groups.

Table 5. Least-square means of free amino acid (FAA) in human milk according to lactation stage (Values in $\mu \mathrm{mol} / \mathrm{L}){ }^{\S, *, \dagger}$.

\begin{tabular}{ccccc}
\hline \multirow{2}{*}{ AA } & \multicolumn{4}{c}{ Lactation Stage } \\
\cline { 2 - 5 } & Colo & Trans & MT2 mo & MT $\geq 2$ mo \\
\hline AA A & \multicolumn{4}{c}{} \\
\hline His & 31.7 & $27.1^{\mathrm{a}}$ & 21.5 & 20.9 \\
Leu & $204.7^{\mathrm{a}}$ & $67.0^{\mathrm{b}}$ & $54.9^{\mathrm{b}}$ & $59.4^{\mathrm{b}}$ \\
Lys & $187.3^{\mathrm{a}}$ & $87.8^{\mathrm{b}}$ & $58.1^{\mathrm{b}}$ & $43.0^{\mathrm{b}}$ \\
Phe & $42.2^{\mathrm{a}}$ & $19.3^{\mathrm{b}}$ & $15.9^{\mathrm{b}}$ & $16.4^{\mathrm{b}}$ \\
Val & $160.1^{\mathrm{a}}$ & $69.2^{\mathrm{b}}$ & $57.4^{\mathrm{b}}$ & $46.3^{\mathrm{b}}$ \\
Thr & $143.1^{\mathrm{a}}$ & $81.6^{\mathrm{b}}$ & $79.1^{\mathrm{b}}$ & $92.9^{\mathrm{b}}$ \\
Met & $34.1^{\mathrm{a}}$ & $18.3^{\mathrm{b}}$ & $10.1^{\mathrm{bc}}$ & $4.0^{\mathrm{c}}$ \\
Ile & $55.1^{\mathrm{a}}$ & $31.6^{\mathrm{ab}}$ & $14.2^{\mathrm{b}}$ & $8.6^{\mathrm{b}}$ \\
Tau & $452.8^{\mathrm{a}}$ & $386.1^{\mathrm{ab}}$ & $287.1^{\mathrm{bc}}$ & $237.9^{\mathrm{c}}$ \\
\hline
\end{tabular}


Table 5. Cont.

\begin{tabular}{|c|c|c|c|c|}
\hline$D A A$ & & & & \\
\hline Arg & $94.3^{a}$ & $35.6^{b}$ & $30.2^{b}$ & $31.5^{b}$ \\
\hline Ala & 218.5 & 189.4 & 199.9 & 224.5 \\
\hline$A s p$ & $114.3^{\mathrm{a}}$ & $60.7^{\mathrm{b}}$ & $55.3^{b}$ & $58.4^{b}$ \\
\hline Tyr & $72.4^{\mathrm{a}}$ & $25.8^{\mathrm{b}}$ & $22.3^{b}$ & $22.1^{b}$ \\
\hline Pro & $172.0^{\mathrm{a}}$ & $70.5^{b}$ & $49.1^{b}$ & $61.7^{b}$ \\
\hline Gly & 84.6 & 81.4 & 84.0 & 101.4 \\
\hline Ser & 122.5 & 80.9 & 99.8 & 128.9 \\
\hline Glu & $1089.9^{b}$ & $960.1^{b}$ & $1175.0^{\mathrm{ab}}$ & $1529.0^{\mathrm{a}}$ \\
\hline Gln & $13.5^{\mathrm{c}}$ & $92.6^{\mathrm{bc}}$ & $134.6^{\mathrm{ab}}$ & $225.8^{a}$ \\
\hline Cys & 27.5 & 30.5 & 32.2 & 28.3 \\
\hline
\end{tabular}

IAA: Indispensable amino acids are those that are essential to the infant [85]. DAA: Dispensable amino acids are those amino acids that are non-essential [85]. ${ }^{\S}$ Colo (0-5 days), Trans (6-20 days), MT2mo (21-60 days); MT $>2$ mo ( $\geq 61$ days). * Means that do not share a common superscript letter are significantly different $(p<0.05) .{ }^{\dagger}$ Includes milk from term, preterm and not-specified groups.

Figure 1. TAA content in human milk according to continent of milk collection (Values are means $\pm \mathrm{SE})$. * Means that do not share a common superscript letter are significantly different $(p<0.05) .{ }^{\dagger}$ Includes milk from term and not-specified (NS) groups.

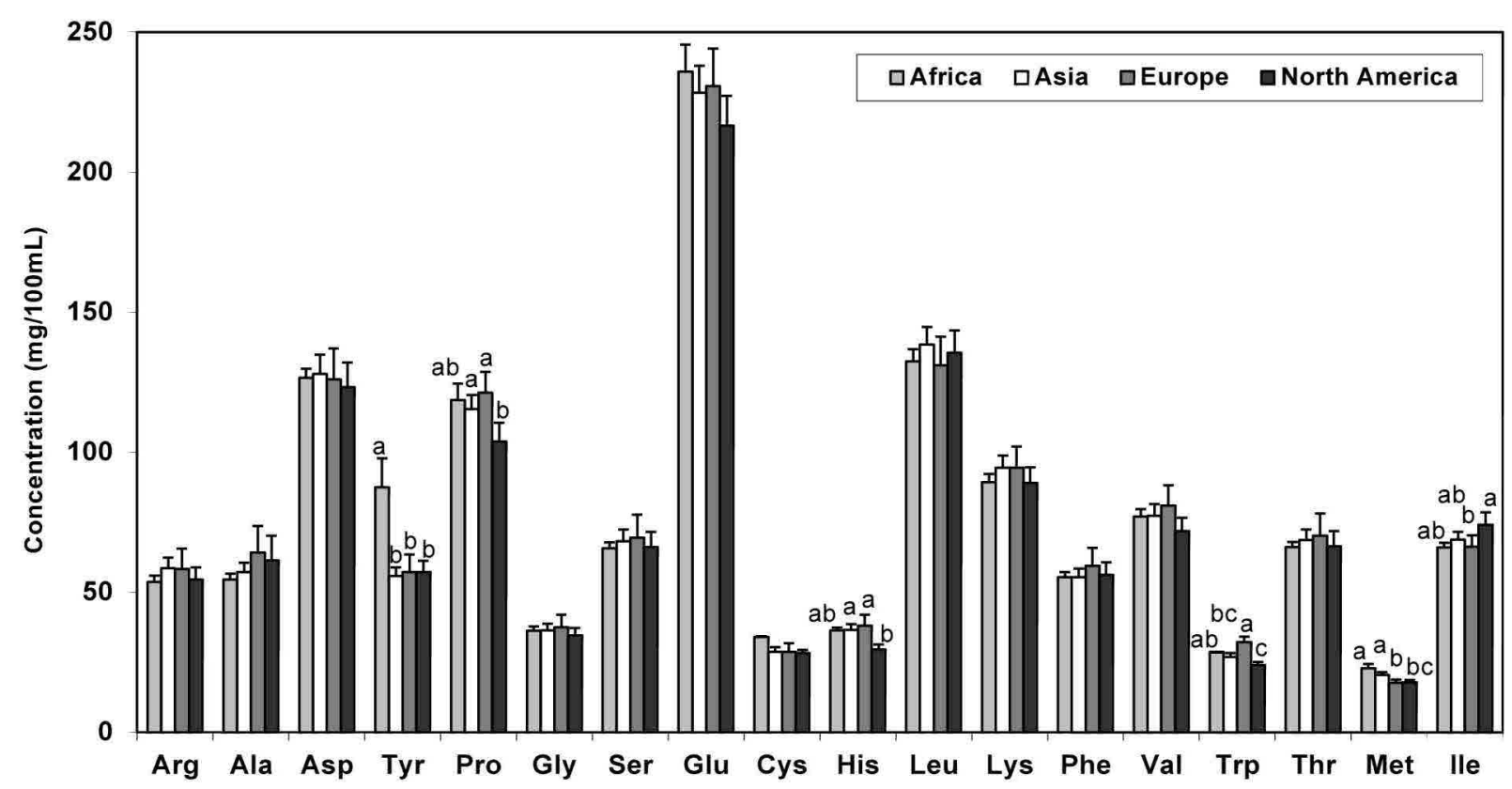


Figure 2. FAA content in human milk according to continent of milk collection (Values are means $\pm \mathrm{SE}) .{ }^{*}$ Means that do not share a common superscript letter are significantly different $(p<0.05) .{ }^{\dagger}$ Includes milk from term and not-specified (NS) groups.

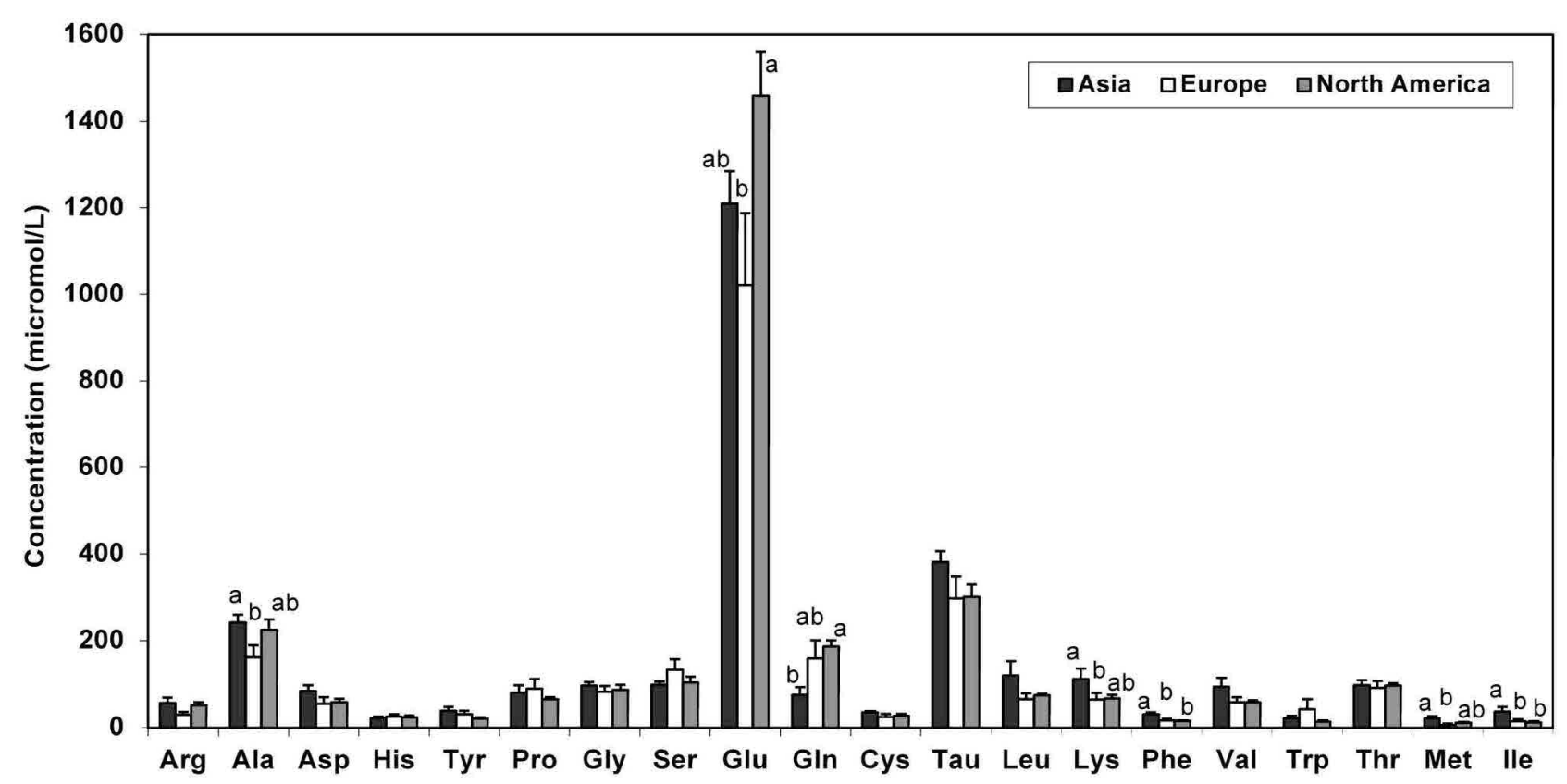

As not all studies provided a gestational age, the non-specified (NS) and term groups were also compared. Results showed that the indispensable amino acids (IAA) lysine, phenylalanine, histidine, and methionine and the dispensable amino acids (DAA) aspartate, glutamate, serine, and cysteine were higher in term human milk than the NS group (Figure 3).

Concentrations of free amino acids in term milk were compared to preterm human milk, as well as the not-specified (NS) group (Table 7). Overall, the levels of FAA were similar between term and preterm milk, with the exception of glutamine, which was significantly lower by nearly one half in preterm than term human milk (Table 7).

\subsection{Comparison to Global Human Milk Standards}

Results of the indispensable and dispensable TAA data from term human milk in this systematic review are remarkably similar to the recommendations of the Scientific Committee on Food (SCF) 2003 (European Commission, 2003) and ESPGHAN 2005/CODEX 2007 [86], with the exception of phenylalanine being lower in our data set (Table 8). Conversely, the values of the Life Sciences Research Office (LSRO), 1998 [1], and the World Health Organization (WHO), 2007 [87], are considerably lower than the concentrations obtained from this data set. 
Table 6. Least-square means of TAA and TN in transitional term milk compared to transitional preterm milk (Amino acid values in $\mathrm{mg} / 100 \mathrm{~mL}$; TN values in $\mathrm{g} / \mathrm{L}$ ) $*$, .

\begin{tabular}{|c|c|c|}
\hline \multirow{2}{*}{$\boldsymbol{A} \boldsymbol{A}$} & \multicolumn{2}{|c|}{ Gestation Period } \\
\hline & Preterm & Term \\
\hline \multicolumn{3}{|c|}{$I A A$} \\
\hline His & 41.7 & 34.5 \\
\hline $\mathrm{Leu}$ & 192.4 & 159.3 \\
\hline Lys & 134.7 & 107.8 \\
\hline Phe & 79.1 & 63.8 \\
\hline Val & $117.1^{\mathrm{a}}$ & $83.3^{b}$ \\
\hline $\operatorname{Trp}$ & 32.1 & 21.4 \\
\hline$T h r$ & $102.1^{\mathrm{a}}$ & $68.4^{b}$ \\
\hline Met & 27.8 & 21.1 \\
\hline Ile & 95.5 & 84.0 \\
\hline \multicolumn{3}{|c|}{$D A A$} \\
\hline $\operatorname{Arg}^{\dagger}$ & $93.8^{\mathrm{a}}$ & $64.9^{b}$ \\
\hline Ala & 90.9 & 56.8 \\
\hline$A s p$ & 174.4 & 130.1 \\
\hline$T y r^{\dagger}$ & 88.3 & 68.8 \\
\hline Pro & 153.0 & 128.2 \\
\hline Gly $^{\dagger}$ & 55.0 & 41.7 \\
\hline $\mathrm{Ser}$ & 111.8 & 90.2 \\
\hline Glu & 305.3 & 252.9 \\
\hline$C y s^{\dagger}$ & 32.0 & 28.0 \\
\hline$T N$ & 3.5 & 2.8 \\
\hline
\end{tabular}

IAA: Indispensable amino acids are those that are essential to the infant [85]. DAA: Dispensable amino acids are those amino acids that are non-essential [85]. * Means that do not share a common superscript letter are significantly different $(p<0.05) .{ }^{\dagger}$ Cysteine, taurine, tyrosine, arginine and glycine may be considered conditionally essential amino acids for the preterm infant [13]. ${ }^{\S}$ Transitional milk defined as 6-20 days lactation.

Figure 3. Least-square means of TAA in term human milk compared to not-specified (NS) milk (Values are means $\pm \mathrm{SE}$ ). * Means that do not share a common superscript letter are significantly different $(p<0.05)$.




Table 7. Least-square means of FAA in term milk compared to preterm human milk and not-specified (NS) group (Values in $\mu \mathrm{mol} / \mathrm{L}) *$.

\begin{tabular}{|c|c|c|c|}
\hline \multirow{2}{*}{$\mathbf{A A}$} & \multicolumn{3}{|c|}{ Gestation Periods } \\
\hline & Preterm & Term & NS \\
\hline \multicolumn{4}{|c|}{$I A A$} \\
\hline His & 19.8 & 28.6 & 27.4 \\
\hline Leu & $80.6^{\mathrm{ab}}$ & $65.0^{\mathrm{b}}$ & $143.9^{\mathrm{a}}$ \\
\hline Lys & 104.0 & 76.0 & 102.2 \\
\hline Phe & 21.1 & 23.9 & 25.4 \\
\hline Val & 79.9 & 73.0 & 96.9 \\
\hline$T h r$ & 82.9 & 92.6 & 121.9 \\
\hline Met & 17.1 & 16.1 & 16.7 \\
\hline Ile & 23.0 & 32.7 & 26.5 \\
\hline $\operatorname{Tau}^{\dagger}$ & $366.7^{\mathrm{ab}}$ & $387.4^{\mathrm{a}}$ & $268.8^{b}$ \\
\hline \multicolumn{4}{|c|}{$D A A$} \\
\hline $\operatorname{Arg}^{\dagger}$ & 56.7 & 36.7 & 50.2 \\
\hline Ala & 181.7 & 210.9 & 231.6 \\
\hline$A s p$ & 67.8 & 77.9 & 70.9 \\
\hline$T y r^{\dagger}$ & 33.1 & 34.9 & 38.9 \\
\hline Pro & 92.4 & 68.3 & 104.3 \\
\hline Gly & 81.5 & 99.3 & 82.8 \\
\hline Ser & 76.0 & 125.0 & 123.0 \\
\hline Glu & 1201.2 & 1168.1 & 1196.2 \\
\hline$G l n$ & $52.9^{b}$ & $159.9^{\mathrm{a}}$ & $137.0^{\mathrm{ab}}$ \\
\hline$C y s^{\dagger}$ & 21.9 & 31.7 & 35.2 \\
\hline
\end{tabular}

IAA: Indispensable amino acids are those that are essential to the infant [85]. DAA: Dispensable amino acids are those amino acids that are non-essential [85]. * Means that do not share a common superscript letter are significantly different $(p<0.05) .{ }^{\dagger}$ Cysteine, taurine, tyrosine, arginine and glycine may be considered conditionally essential amino acids for the preterm infant [13]. 
Table 8. Comparison of present analysis to global TAA standards (Values in $\mathrm{mg} / \mathrm{g} \mathrm{TN})^{\dagger}$.

\begin{tabular}{|c|c|c|c|c|c|c|c|}
\hline & $\begin{array}{l}\text { Present } \\
\text { Analysis }\end{array}$ & $\begin{array}{c}\text { Koletzko 2005; } \\
\text { CODEX 2007 }[86,88] \\
\end{array}$ & LSRO 1998 [1] & $\begin{array}{c}\text { Panel of Macronutrients 2005; } \\
\text { Kleinman } 2009[89,90]\end{array}$ & $\begin{array}{c}\text { USDA } \\
2009[91]\end{array}$ & $\begin{array}{c}\text { European } \\
\text { Commission 2003 [92] } \\
\end{array}$ & $\begin{array}{c}\text { WHO/FAO } \\
2007 \text { [87] }\end{array}$ \\
\hline No. of Studies & 26 & 7 & 4 & 4 & $*$ & 6 & 3 \\
\hline \multicolumn{8}{|c|}{$I A \boldsymbol{A}$} \\
\hline His & $143 \pm 2.8$ & 141 & $*$ & 112.13 & 136.72 & 137.5 & 102.38 \\
\hline Leu & $570 \pm 8.1$ & 586 & 491.4 & 492.38 & 566.41 & 575 & 468 \\
\hline$L y s$ & $389 \pm 6.0$ & 395 & 355.39 & 336.38 & 410.16 & 393.5 & 336.38 \\
\hline Phe & $224 \pm 6.2$ & 282 & 181.84 & 195.0 & 273.44 & 287.5 & 204.75 \\
\hline Val & $318 \pm 6.0$ & 315 & 258.38 & 273.0 & 371.09 & 306.25 & 268.13 \\
\hline $\operatorname{Trp}$ & $111 \pm 2.8$ & 114 & 75.56 & 87.75 & 97.66 & 112.5 & 82.88 \\
\hline$T h r$ & $263 \pm 3.4$ & 268 & 220.35 & 229.13 & 273.44 & 268.75 & 214.5 \\
\hline Met & $86 \pm 1.8$ & 85 & 71.66 & 78.0 & 117.19 & 81.25 & 78 \\
\hline Ile & $305 \pm 5.0$ & 319 & 251.55 & 277.83 & 332.03 & 312.5 & 268.13 \\
\hline \multicolumn{8}{|c|}{$D A A$} \\
\hline $\operatorname{Arg}$ & $211 \pm 3.2$ & 196 & $*$ & $*$ & 253.91 & $*$ & 112.13 \\
\hline Ala & $221 \pm 4.2$ & $*$ & $*$ & $*$ & 214.84 & $*$ & 185.25 \\
\hline$A s p$ & $503 \pm 6.7$ & $*$ & $*$ & $*$ & 488.28 & $*$ & $*$ \\
\hline Tyr & $242 \pm 8.1$ & 259 & 199.88 & 229.13 & 312.5 & 262.5 & 253.5 \\
\hline Pro & $498 \pm 9.0$ & $*$ & $*$ & $*$ & 488.28 & $*$ & 390 \\
\hline Gly & $135 \pm 2.0$ & $*$ & $*$ & $*$ & 156.25 & $*$ & 112.13 \\
\hline Ser & $256 \pm 9.0$ & $*$ & $*$ & $*$ & 253.91 & $*$ & 243.75 \\
\hline Glu & $994 \pm 14.7$ & $*$ & $*$ & $*$ & 1015.63 & $*$ & $*$ \\
\hline Cys & $117 \pm 2.9$ & 131 & 94.09 & 107.25 & 117.19 & 131.25 & 82.88 \\
\hline$A s p+A s n$ & & & & & & & 438.75 \\
\hline Glu + Gln & & & & & & & 867.75 \\
\hline
\end{tabular}

IAA: Indispensable amino acids are those that are essential to the infant [85]. DAA: Dispensable amino acids are those amino acids that are non-essential [85]. ${ }^{\dagger}$ Includes milk from term and not-specified (NS) groups. * Data not available. 


\section{Discussion}

The complete characterization and quantitation of protein and non-protein nitrogen in human milk serves as an appropriate nutritional guide for understanding and defining an infant's protein and amino acid requirements. The amino acid content of human milk is comprised of TAA and FAA, and FAA make up a significant component of NPN, $\sim 8 \%-22 \%$ in human milk [4,5]. FAA enter into the circulation sooner after ingestion than protein-derived amino acids, and their rapid absorption contributes significantly to the initial changes in FAA levels in the infant's plasma $[3,11,93]$. FAA, however, are typically overlooked in the scientific literature focusing on protein composition. Therefore, our objective was to compile a comprehensive database characterizing both the TAA and FAA content of human milk to better understand the quantitative and qualitative changes in amino acid composition through lactation.

To this end, we collected data, published as early as 1941 to 2010, from more than 70 studies to ascertain if gestational age, lactation stage, and geographical region significantly influence levels of total and free amino acids in preterm and term human milk. Overall, we observed that TAA (and TN) values were relatively consistent among studies; however, the effects of lactation stage, gestational age, and geographical origin still need to be considered, since these appear to influence the amino acid profiles and $\mathrm{TN}$ values.

Results from this study confirm that a majority of the variation in amino acid composition of human milk is caused by stage of lactation. The greatest decline in TAA concentration occurs over the first 4 mo of lactation with levels remaining relatively stable thereafter (Table 4). This correlates to the changing protein needs of the growing infant [94]. Interestingly, some FAA (alanine, glycine, serine, glutamine, and glutamate) increase with progressing lactation. For instance, glutamine was nearly 20 times higher in mature milk than its lowest value in colostrum (Table 5). Glutamate, known as the most abundant FAA, has many beneficial functions to the growing infant by providing ketoglutaric acid for the citric acid cycle, possibly acting as a neurotransmitter in the brain, and serving as a major energy substrate for intestinal cells [3]. Recently, it was suggested that the high levels of free glutamate in breast milk and extensively hydrolyzed formula are responsible for the lower daily intakes of these diets [95]. It has also been proposed that very low-birth weight infants receiving glutamine supplementation have less tissue catabolism and enhanced gluconeogenesis [96]. Once again, the full physiological importance of all the FAA to infant growth and development has yet to be established [12,50].

It has often been reported that the amino acid pattern and overall protein concentration of preterm milk are generally similar to those of term milk [44,97]. On an absolute basis, our comparison of preterm and term milk showed that $\mathrm{TN}$ and all AA were higher in concentration in preterm than in term milk (Table 6), which is consistent with other studies that reported significantly higher concentrations of protein [36,98] and total nitrogen [99] in preterm milk than term human milk. These results indicate that preterm milk may be a more appropriate source of protein and certain amino acids than term milk to accommodate for the rapid growth rates of premature infants. However, our study focused only on a few studies from the transitional stage of lactation in preterm milk, and significant differences were only observed for valine, threonine, and arginine; whereas, amino acid patterns through lactation were not addressed in this study (Table 6). 
There have been discussions as to whether the concentration and proportion of NPN in preterm human milk is significantly different from that of term milk [2,44,100-102]. Similarly, the influences of gestational age on the level of individual free amino acids remain uncertain. The concentrations of most FAA from this analysis were similar in term and preterm milk (Table 7). Our analysis, however, is limited to a handful of available published studies on preterm milk. These data emphasize the need to carefully consider not only the total protein needs but also the essential and non-essential amino acid requirements of preterm infants. These differences in preterm and term human milk also reiterate the need for more research associated with longer lactation periods, especially given the increased survival rates of preterm infants born at earlier gestational ages.

Significant differences among the different geographical regions were observed for a handful of TAA (tyrosine, proline, histidine, methionine, and tryptophan) and FAA (lysine, phenylalanine, methionine, and isoleucine). Results from Feng et al. (2009) showed total amino acid profiles were similar across nine different countries [27], agreeing with the present study. Some research indicates that maternal diet quality may influence TAA and FAA in mothers' milk [53,103], yet in other studies protein content is well preserved in mothers consuming protein deficient diets [104,105]. Although we excluded data from mothers consuming experimental diets, we did not exclude data from mothers whose typical diets may have had lower protein quality or inadequate intake. However, a more recent study showed no relation between the amino acid concentration in maternal diet and milk of women in Northern China [106].

In contrast to the TAA data, the values for FAA showed large inter-study variability. Previously published data on the concentration of FAA in human milk show wide variations, depending on corresponding stages of lactation [6,50,53]. For example, Carratù et al. observed differences in median and mean values after analysis of 195 samples in the first month of lactation, despite careful standardization of collection procedures to minimize variation in FAA values [5]. The differences between median and mean values indicated an abnormal distribution of data, especially for those amino acids present in traces, which may be a characteristic of human milk [5].

\section{Conclusions}

This systematic review offers a thorough characterization of human milk total and free amino acid patterns throughout the course of lactation and across several geographical areas. It represents a useful dataset for the evaluation of protein quality and quantity of breast milk substitutes for preterm and term infants. Its comprehensive nature may also serve as a guide to support future efforts in the establishment and revision of global and/or regional human milk amino acid reference values throughout the first year of life.

\section{Acknowledgments}

This project was supported by Mead Johnson Pediatric Nutrition Institute, Evansville, IN, USA. 


\section{Conflicts of Interest}

Z. Zhang, A. Adelman, D. Rai and J. Boettcher were employed by Mead Johnson Pediatric Nutrition Institute when the work was conducted. B. Lőnnerdal declares no conflict of interest.

\section{References}

1 Raiten, D.J.; Talbot, J.M.; Waters, J.H. Assessment of nutrient requirements of infant formulas. J. Nutr. 1998, 128, 2116S-2118S.

2 Lemons, J.A.; Reyman, D.; Moye, L. Amino acid composition of preterm and term breast milk during early lactation. Early Hum. Dev. 1983, 8, 323-329.

3 Agostoni, C.; Carratù, B.; Boniglia, C.; Lammardo, A.M.; Riva, E.; Sanzini, E. Free glutamine and glutamic acid increase in human milk through a three-month lactation period. J. Pediatr. Gastroenterol. Nutr. 2000, 31, 508-512.

4 Atkinson, S.A.; Schnurr, C.; Donovan, S.M.; Lönnerdal, B. The Non-Protein Nitrogen Components of Human Milk: Biochemistry and Potential Functional Role. In Protein and Non-Protein Nitrogen in Human Milk; Atkinson, S.A., Lönnerdal, B., Eds.; CRC Press: Boca Raton, FL, USA, 1989; pp. 117-133.

5 Carratù, B.; Boniglia, C.; Scalise, F.; Ambruzzi, A.; Sanzini, E. Nitrogenous components of human milk: Non-protein nitrogen, true protein and free amino acids. Food Chem. 2003, 81, $357-362$.

6 Svanberg, U.; Gebre-Medhin, M.; Ljungqvist, B.; Olsson, M. Breast milk composition in Ethiopian and Swedish mothers. III. Amino acids and other nitrogenous substances. Am. J. Clin. Nutr. 1977, 30, 499-507.

7 Agostoni, C.; Carratù, B.; Boniglia, C.; Riva, E.; Sanzini, E. Free amino acid content in standard infant formulas: Comparison with human milk. J. Am. Coll. Nutr. 2000, 19, 434-438.

8 Chuang, C.K.; Lin, S.P.; Lee, H.C.; Wang, T.J.; Shih, Y.S.; Huang, F.Y.; Yeung, C.Y. Free amino acids in full-term and pre-term human milk and infant formula. J. Pediatr. Gastroenterol. Nutr. 2005, 40, 496-500.

9 Elmastas, M.; Keha, E.E.; Keles, M.S.; Aboul-Enein, H.Y. Analysis of free amino acids and protein contents of mature human milk from Turkish mothers. Anal. Lett. 2008, 41, 725-736.

10 Sarwar, G. Comparative free amino acid profiles of human milk and some infant formulas sold in Europe. J. Am. Coll. Nutr. 2001, 20, 92-93.

11 Pamblanco, M.; Portolés, M.; Paredes, C.; Ten, A.; Comín, J. Free amino acids in preterm and term milk from mothers delivering appropriate- or small-for-gestational-age infants. Am. J. Clin. Nutr. 1989, 50, 778-781.

12 Ferreira, I.M. Quantification of non-protein nitrogen components of infant formulae and follow-up milks: Comparison with cows' and human milk. Br. J. Nutr. 2003, 90, 127-133.

13 Klein, C.J. Nutrient requirements for preterm infant formulas. J. Nutr. 2002, 132, 1395S-1577S. 
14 Agostoni, C.; Buonocore, G.; Carnielli, V.P.; de Curtis, M.; Darmaun, D.; Decsi, T.; Domellof, M.; Embleton, N.D.; Fusch, C.; Genzel-Boroviczeny, O.; et al. Enteral nutrient supply for preterm infants: Commentary from the European Society of Paediatric Gastroenterology, Hepatology and Nutrition Committee on Nutrition. J. Pediatr. Gastroenterol. Nutr. 2010, 50, 85-91.

15 Britton, J.R. Milk protein quality in mothers delivering prematurely: Implications for infants in the intensive care unit nursery setting. J. Pediatr. Gastroenterol. Nutr. 1986, 5, 116-121.

16 Lönnerdal, B.; Smith, C.; Keen, C.L. Analysis of breast milk: Current methodologies and future needs. J. Pediatr. Gastroenterol. Nutr. 1984, 3, 290-295.

17 Donovan, S.M.; Lönnerdal, B. Isolation of the nonprotein nitrogen fraction from human milk by gel-filtration chromatography and its separation by fast protein liquid chromatography. Am. J. Clin. Nutr. 1989, 50, 53-57.

18 Atkinson, S.A. Human Milk Feeding of Premature Infants $<1.3 \mathrm{~kg}$ Birthweight: Milk Analysis and Clinical Studies during Early Postnatal Life; University of Toronto: Toronto, ON, Canada, 1980.

19 Bellomonte, G.; Boniglia, C.; Carratù, B.; Filesi, C.; Giammarioli, S.; Mosca, M.; Sanzini, E. Protein and lipid composition of human milk and infant formulas: Comparison and nutritional consequences. Ann. Ist. Super. Sanita 1990, 26, 131-139.

20 Chavalittamrong, B.; Suanpan, S.; Boonvisut, S.; Chatranon, W.; Gershoff, S.N. Protein and amino acids of breast milk from Thai mothers. Am. J. Clin. Nutr. 1981, 34, 1126-1130.

21 Cheung, M.W.; Pratt, E.L.; Fowler, D.I. Total amino acid composition in mature human milk; analysis by the ion exchange resin column chromatographic technic. Pediatrics 1953, 12, $353-357$.

22 Darling, P. Threonine and Phenylalanine Metabolism in the Human Neonate; University of Toronto: Toronto, ON, Canada, 1997.

23 Darling, P.B.; Dunn, M.; Sarwar, G.; Brookes, S.; Ball, R.O.; Pencharz, P.B. Threonine kinetics in preterm infants fed their mothers' milk or formula with various ratios of whey to casein. Am. J. Clin. Nutr. 1999, 69, 105-114.

24 Darragh, A.J.; Moughan, P.J. The amino acid composition of human milk corrected for amino acid digestibility. Br. J. Nutr. 1998, 80, 25-34.

25 Davis, T.A.; Nguyen, H.V.; Garcia-Bravo, R.; Fiorotto, M.L.; Jackson, E.M.; Reeds, P.J. Amino acid composition of the milk of some mammalian species changes with stage of lactation. Br. J. Nutr. 1994, 72, 845-853.

26 Donovan, S.M.; Lönnerdal, B. Non-protein nitrogen and true protein in infant formulas. Acta Paediatr. Scand. 1989, 78, 497-504.

27 Feng, P.; Gao, M.; Holley, T.; Zhou, T.; Burgher, A.; Trabulsi, J.; Pramuk, K.; Nazzario, J. Amino acid composition and protein content of mature human milk from nine countries. FASEB J. 2009, 23, LB448.

28 Hanning, R.M.; Paes, B.; Atkinson, S.A. Protein metabolism and growth of term infants in response to a reduced-protein, 40:60 whey: Casein formula with added tryptophan. Am. J. Clin. Nutr. 1992, 56, 1004-1011.

29 Harzer, G.; Bindels, J.G. Changes in Human Milk Immunoglobulin A and Lactoferrin during Early Lactation. In Composition and Physiological Properties of Human Milk; Elsevier Science: Amsterdam, The Netherlands, 1985; pp. 285-295. 
30 Janas, L.M.; Picciano, M.F. Quantities of amino acids ingested by human milk-fed infants. J. Pediatr. 1986, 109, 802-807.

31 Janas, L.M.; Picciano, M.F.; Hatch, T.F. Indices of protein metabolism in term infants fed either human milk or formulas with reduced protein concentration and various whey/casein ratios. J. Pediatr. 1987, 110, 838-848.

32 Lauber, E.; Reinhardt, M. Studies on the quality of breast milk during 23 months of lactation in a rural community of the Ivory Coast. Am. J. Clin. Nutr. 1979, 32, 1159-1173.

33 London Department of Health. The Composition of Mature Human Milk. In Report of a Working Party of the Committee on Medical Aspects of Food Policy; HM Stationery Office: London, UK, 1977; pp. xi-47.

34 Lönnerdal, B.; Forsum, E.; Hambraeus, L. The protein content of human milk I. Transversal study of Swedish normal material. Nutr. Rep. Int. 1976, 13, 125-134.

35 Lönnerdal, B.; Forsum, E. Casein content of human milk. Am. J. Clin. Nutr. 1985, 41, 113-120.

36 Sarwar, G.; Darling, P.; Ujiie, M.; Botting, H.G.; Pencharz, P.B. Use of amino acid profiles of preterm and term human milks in evaluating scoring patterns for routine protein quality assessment of infant formulas. J. AOAC Int. 1996, 79, 498-502.

37 Shaikhiev, A.A. Amino acid composition of breast milk in the first month of lactation. Vopr. Okhr. Materin. Det. 1980, 25, 12-15.

38 Villalpando, S.; Butte, N.F.; Flores-Huerta, S.; Thotathuchery, M. Qualitative analysis of human milk produced by women consuming a maize-predominant diet typical of rural Mexico. Ann. Nutr. Metab. 1998, 42, 23-32.

39 Wu, Z.C.; Chuang, C.C.; Lau, B.H.; Hwang, B.; Sugawara, M.; Idota, T. Crude protein content and amino acid composition in Taiwanese human milk. J. Nutr. Sci. Vitaminol. (Tokyo) 2000, 46, 246-251.

40 Yamawaki, N.; Yamada, M.; Kan-no, T.; Kojima, T.; Kaneko, T.; Yonekubo, A. Macronutrient, mineral and trace element composition of breast milk from Japanese women. J. Trace Elem. Med. Biol. 2005, 19, 171-181.

41 Yonekubo, A.; Onoda, T.; Fumikura, M.; Fudota, K.; Tsuchiya, F. Total and free amino acid compositions of human milk from Japan. J. Jap. Soc. Nutr. Grains 1989, 42, 194-196.

42 Zhao, X.; Xu, Z.; Wang, Y.; Sun, Y. Studies of the relation between the nutritional status of lactating mothers and milk composition as well as the milk intake and growth of their infants in Beijing. Pt. 4. The protein and amino acid content of breast milk. Ying Yang Xue Bao 1989, 11, 227-232.

43 Armstrong, M.; Yates, K. Free amino acids in milk. Proc. Soc. Exp. Biol. Med. 1963, 113, 680-684.

44 Atkinson, S.A.; Anderson, G.H.; Bryan, M.H. Human milk: Comparison of the nitrogen composition in milk from mothers of premature and full-term infants. Am. J. Clin. Nutr. 1980, 33, 811-815.

45 DeSantiago, S.; Ramírez, I.; Tovar, A.R.; Alonso, L.; Ortíz-Olaya, N.; Torres, N. Free amino acids in plasma and milk of Mexican rural lactating women. Rev. Investig. Clin. 1998, 50, $405-412$. 
46 Gutikova, L.V. The concentration of amino acids in the breast milk of nursing women. Klin. Lab. Diagn. 2001, 7, 21-24.

47 Harzer, G.; Franzke, V.; Bindels, J.G. Human milk nonprotein nitrogen components: Changing patterns of free amino acids and urea in the course of early lactation. Am. J. Clin. Nutr. 1984, 40, 303-309.

48 López-Sánchez Solís, M.; Pajarón de Ahumada, M.; Cámara Palop, J.; García Campos, M.; Alvarez Martínez, J.A.; Martínez-Artero, I.; Borrajo Guadarrama, E. Free amino acids and hydrolyzed proteins in breast milk. Rev. Esp. Pediatr. 1988, 44, 557-560.

49 Motil, K.J.; Thotathuchery, M.; Bahar, A.; Montandon, C.M. Marginal dietary protein restriction reduced nonprotein nitrogen, but not protein nitrogen, components of human milk. J. Am. Coll. Nutr. 1995, 14, 184-191.

50 Rassin, D.K.; Gaull, G.E.; Heinonen, K.; Räihä, N.C. Milk protein quantity and quality in low-birth-weight infants: II. Effects on selected aliphatic amino acids in plasma and urine. Pediatrics 1977, 59, 407-422.

51 Singh, P.; Saxena, S.K.; Mallick, H.N. Free glutamic acid content of milk in Indian mothers. Indian J. Physiol. Pharmacol. 2004, 48, 365-369.

52 Viña, J.R.; Puertes, I.R.; Rodriguez, A.; Saez, G.T.; Viña, J. Effect of fasting on amino acid metabolism by lactating mammary gland: Studies in women and rats. J. Nutr. 1987, 117, 533-538.

53 Wurtman, J.J.; Fernstrom, J.D. Free amino acid, protein, and fat contents of breast milk from Guatemalan mothers consuming a corn-based diet. Early Hum. Dev. 1979, 3, 67-77.

54 Beach, E.F.; Bernstein, S.; Hoffman, O.D.; Teague, D.M.; Macy, I. Distribution of nitrogen and protein amino aids in human and in cow's milk. J. Biol. Chem. 1941, 139, 57-63.

55 Block, R.; Bolling, D. The amino acid composition of cow and human milk proteins. Arch. Biochem. 1946, 10, 359-363.

56 Davis, T.A.; Fiorotto, M.L.; Reeds, P.J. Amino acid compositions of body and milk protein change during the suckling period in rats. J. Nutr. 1993, 123, 947-956.

57 Davis, T.A.; Nguyen, H.V.; Garcia-Bravo, R.; Fiorotto, M.L.; Jackson, E.M.; Lewis, D.S.; Lee, D.R.; Reeds, P.J. Amino acid composition of human milk is not unique. J. Nutr. 1994, 124, $1126-1132$.

58 DeSantiago, S.; Ramírez, I.; Tovar, A.R.; Ortíz, N.; Torres, N.; Bourges, H. Amino acid profiles in diet, plasma, and human milk in Mexican rural lactating women. Nutr. Res. 1999, 19, $1133-1143$.

59 Filippova, G.I.; Aronova, B.N. Amino acid composition of human milk at different periods of lactation and effect on it of hedge nettle extract administered in the early puerperal. Zdravookhr. Kirg. 1974, 6, 24-26.

60 Guo, H.Y.; Pang, K.; Zhang, X.Y.; Zhao, L.; Chen, S.W.; Dong, M.L.; Ren, F.Z. Composition, physiochemical properties, nitrogen fraction distribution, and amino acid profile of donkey milk. J. Dairy Sci. 2007, 90, 1635-1643.

61 Heine, W.E.; Klein, P.D.; Reeds, P.J. The importance of alpha-lactalbumin in infant nutrition. J. Nutr. 1991, 121, 277-283. 
62 Järvenpää, A.L.; Rassin, D.K.; Räihä, N.C.; Gaull, G.E. Milk protein quantity and quality in the term infant. II. Effects on acidic and neutral amino acids. Pediatrics 1982, 70, 221-230.

63 Macy, I.G. Composition of human colostrum and milk. Am. J. Dis. Child. 1949, 78, 589-603.

64 Macy, I.; Kelly, H.J. Human and Cow's Milk in Infant Nutrition. In Milk the Mammary Gland and Its Secretion; Kon, S.K., Cowie, A.T., Eds.; Acadmeic Press: New York, NY, USA, 1961; Volume 2, pp. 265-304.

65 Miller, S.; Ruttinger, V.; Frahm, R.; Maurer, S.; Moyer, E.; Kaucher, M.; Macy, I. Human milk studies XXVII. Essential amino acids in colostrum and transitional milk. J. Nutr. 1950, 40, 499-541.

66 Mitton, S.G.; Garlick, P.J. Changes in protein turnover after the introduction of parenteral nutrition in premature infants: Comparison of breast milk and egg protein-based amino acid solutions. Pediatr. Res. 1992, 32, 447-454.

67 Nagasawa, T.; Kiyosawa, I.; Kuwahara, K. Acrylamide gel electrophoresis and amino acid compositions of human colostral casein. J. Dairy Sci. 1970, 53, 92-94.

68 Nayman, R.; Thomson, M.E.; Scriver, C.R.; Clow, C.L. Observations on the composition of milk-substitute products for treatment of inborn errors of amino acid metabolism. Comparisons with human milk. A proposal to rationalize nutrient content of treatment products. Am. J. Clin. Nutr. 1979, 32, 1279-1289.

69 Picone, T.A.; Benson, J.D.; Moro, G.; Minoli, I.; Fulconis, F.; Rassin, D.K.; Räihä, N.C. Growth, serum biochemistries, and amino acids of term infants fed formulas with amino acid and protein concentrations similar to human milk. J. Pediatr. Gastroenterol. Nutr. 1989, 9, 351-360.

70 Räihä, R.; Fazzolari Nesci, A.; Cajozzo, C.; Puccio, G.; Minoli, I.; Moro, G.E.; Monestier, A.; Haschke-Becher, E.; Carrie, A.L.; Haschke, F. Protein quantity and quality in infant formula: Closer to the reference. Nestle Nutr. Workshop Ser. Pediatr. Program 2002, 47, 111-120.

71 Renner, E. Milk Protein. In Milk and Dairy Products in Human Nutrition; Renner, E., Ed.; Friedrich Pustet: Regensburg, Germany, 1983; pp. 90-129.

72 Rigo, J.; Salle, B.L.; Cavero, E.; Richard, P.; Putet, G.; Senterre, J. Plasma amino acid and protein concentrations in infants fed human milk or a whey protein hydrolysate formula during the first month of life. Acta Paediatr. 1994, 83, 127-131.

73 Saito, K.; Furuichi, E.; Kondo, S.; Kawanishi, G.; Nishikawa, I.; Nakazato, H.; Noguchi, Y.; Doi, T.; Noguchi, A.; Shingo, S. Studies on Human Milk; Snow Brand Products: Tokyo, Japan, 1975; pp. 1-112.

74 Scott, P.H.; Sandham, S.; Balmer, S.E.; Wharton, B.A. Diet-related reference values for plasma amino acids in newborns measured by reversed-phase HPLC. Clin. Chem. 1990, 36, 1922-1927.

75 Soupart, P.; Moore, S.; Bigwood, E.J. Amino acid composition of human milk. J. Biol. Chem. 1954, 206, 699-704.

76 Tikanoja, T.; Simell, O.; Viikari, M.; Järvenpää, A.L. Plasma amino acids in term neonates after a feed of human milk or formula. II. Characteristic changes in individual amino acids. Acta Paediatr. Scand. 1982, 71, 391-397.

77 Volz, V.R.; Book, L.S.; Churella, H.R. Growth and plasma amino acid concentrations in term infants fed either whey-predominant formula or human milk. J. Pediatr. 1983, 102, 27-31. 
78 Williamson, M.B. The amino acid composition of human milk proteins. J. Biol. Chem. 1944, $156,47-52$.

79 Woodward, D.R.; Messer, M. Chemical composition of rat casein. Comp. Biochem. Physiol. B 1976, 55, 141-143.

80 Farriauz, J.P.; Razemon-Pinta, M.; Fontaine, G. The free amino acids of milk. Revue Pediatr. 1971, 9, 639-670.

81 Faus, O.; Lopez Morales, J.; Faus, M.J.; Periago, J.L.; Bueno Sánchez, A.; Gil, A.; Martínez Valverde, A. Content of free amino acids in human milk in Spain. An. Esp. Pediatr. 1984, 21, 557-563 (in Spanish).

82 Ghadimi, H.; Pecora, P. Free amino acids of different kinds of milk. Am. J. Clin. Nutr. 1963, 13, 75-81.

83 Pajarón, M.; López Sánchez Solís, M.; Morán, J. Quantification of free amino acids in human milk. Rev. Esp. Pediatr. 1992, 48, 303-308.

84 Periago, J.L.; Faus, O.; Martínez Valverde, A.; Bueno Sánchez, A.; Faus, M.J.; Gil, A. Content of free amino acids in some milk formulas used in Spain. An. Esp. Pediatr. 1984, 21, 635-641.

85 Rassin, D.K. Essential and Non-Essential Amino Acids in Neonatal Nutrition. In Protein Metabolism During Infancy; Räihä, N.C.R., Ed.; Raven Press: New York, NY, USA, 1994; Volume 33, pp. 183-192.

86 Koletzko, B.; Baker, S.; Cleghorn, G.; Neto, U.F.; Gopalan, S.; Hernell, O.; Hock, Q.S.; Jirapinyo, P.; Lönnerdal, B.; Pencharz, P.; et al. Global standard for the composition of infant formula: Recommendations of an ESPGHAN coordinated international expert group. J. Pediatr. Gastroenterol. Nutr. 2005, 41, 584-599.

87 World Health Organization. Protein and Amino Acid Requirements in Human Nutrition. In Report of a Joint WHO/FAO/UNU Consultation; World Health Organization: Geneva, Switzerland, 2007; pp. 161-182.

88 CODEX Alimentarius Standard for Infant Formula and Formulas for Special Medical Purposes Intended for Infants. In CODEX STAN 72-1981; CODEX Alimentarius: Rome, Italy, 2007; pp. 2-21.

89 Panel on Macronutrients; Panel on the Definition of Dietary Fiber; Subcommittee on Upper Reference Levels of Nutrients; Subcommittee on Interpretation and Uses of Dietary Reference Intakes. Standing Committee on the Scientific Evaluation of Dietary Reference Intakes, Protein and Amino Acids. In Dietary Reference Intakes for Energy, Carbohydrate, Fiber, Fat, Fatty Acids, Cholesterol, Protein, and Amino Acids; National Academies Press: Washington, DC, USA, 2005; pp. 589-768.

90 Kleinman, R. Pediatric Nutrition Handbook, 6th ed.; American Academy of Pediatrics: Elk Grove Village, IL, USA, 2009.

91 USDA. USDA National Nutrient Database for Standard Reference, Release 22; USDA: Washington, DC, USA, 2009.

92 European Commission Scientific Committee on Food. Report of the Scientific Committee on Food on the Revision of Essential Requirements of Infant Formulae and Follow-on Formulae (Adopted on 4 April 2003); European Commission: Brussels, Belgium, 2003. 
93 Schanler, R.J.; Garza, C. Plasma amino acid differences in very low birth weight infants fed either human milk or whey-dominant cow milk formula. Pediatr. Res. 1987, 21, 301-305.

94 Dupont, C. Protein requirements during the first year of life. Am. J. Clin. Nutr. 2003, 77, 1544S-1549S.

95 Ventura, A.K.; Beauchamp, G.K.; Mennella, J.A. Infant regulation of intake: The effect of free glutamate content in infant formulas. Am. J. Clin. Nutr. 2012, 95, 875-881.

96 Roig, J.C.; Meetze, W.H.; Auestad, N.; Jasionowski, T.; Veerman, M.; McMurray, C.A.; Neu, J. Enteral glutamine supplementation for the very low birthweight infant: Plasma amino acid concentrations. J. Nutr. 1996, 126, 1115S-1120S.

97 Molinari, C.E.; Casadio, Y.S.; Hartmann, B.T.; Livk, A.; Bringans, S.; Arthur, P.G.; Hartmann, P.E. Proteome mapping of human skim milk proteins in term and preterm milk. J. Proteome Res. 2012, 11, 1696-1714.

98 Bauer, J.; Gerss, J. Longitudinal analysis of macronutrients and minerals in human milk produced by mothers of preterm infants. Clin. Nutr. 2011, 30, 215-220.

99 Armaforte, E.; Curran, E.; Huppertz, T.; Ryan, A.; Caboni, M.F.; O’Connor, P.M.; Ross, R.P.; Hirtz, C.; Sommerer, N.; Chevalier, F.; et al. Proteins and proteolysis in pre-term and term human milk and possible implications for infant formulae. Int. Dairy J. 2010, 20, 715-723.

100 Beijers, R.J.; Graaf, F.V.; Schaafsma, A.; Siemensma, A.D. Composition of premature breast-milk during lactation: Constant digestible protein content (as in full term milk). Early Hum. Dev. 1992, 29, 351-356.

101 Gross, S.J.; David, R.J.; Bauman, L.; Tomarelli, R.M. Nutritional composition of milk produced by mothers delivering preterm. J. Pediatr. 1980, 96, 641-644.

102 Lepage, G.; Collet, S.; Bougle, D.; Kien, L.C.; Lepage, D.; Dallaire, L.; Darling, P.; Roy, C.C. The composition of preterm milk in relation to the degree of prematurity. Am. J. Clin. Nutr. 1984, 40, 1042-1049.

103 Lindblad, B.S.; Rahimtoola, R.J. A pilot study of the quality of human milk in a lower socio-economic group in Karachi, Pakistan. Acta Paediatr. Scand. 1974, 63, 125-128.

104 Lönnerdal, B. Effects of maternal dietary intake on human milk composition. J. Nutr. 1986, 116, 499-513.

105 Trugo, N.M.; Donangelo, C.M.; Koury, J.C.; Silva, M.I.; Freitas, L.A. Concentration and distribution pattern of selected micronutrients in preterm and term milk from urban Brazilian mothers during early lactation. Eur. J. Clin. Nutr. 1988, 42, 497-507.

106 Ding, M.; Li, W.; Zhang, Y.; Wang, X.; Zhao, A.; Zhao, X.; Wang, P.; Sheng, Q.H. Amino acid composition of lactating mothers' milk and confinement diet in rural North China. Asia Pac. J. Clin. Nutr. 2010, 19, 344-349.

(C) 2013 by the authors; licensee MDPI, Basel, Switzerland. This article is an open access article distributed under the terms and conditions of the Creative Commons Attribution license (http://creativecommons.org/licenses/by/3.0/). 